\title{
In vitro digestibility and proteases inhibitory effect of several feedstuffs for Parachromis dovii juveniles and $P$. dovii hybrid larvae
}

\author{
Silvia Valverde-Chavarría • Carlos A. Álvarez-González • Miguel Brais-Medina • \\ Elman Calvo-Elizondo $\cdot$ Juan B. Ulloa-Rojas
}

Received: 29 February 2016/Accepted: 21 June 2016

(C) Springer Science+Business Media Dordrecht 2016

\begin{abstract}
Parachromis dovii, a native cichlid from Costa Rica, is highly appreciated for its size and flesh quality. Further, $P$. dovii easily accept inert feed from the beginning of exogenous feeding; however, its growth is low compared to live food. For this reason, evaluation of several feedstuffs using two in vitro techniques was done. The quantification of the in vitro inhibitory effect of seven plant ingredients on the alkaline protease activity was done using enzymatic extracts from larvae samples of 6, 15, 22 and 30 days after hatching (DAH). The in vitro alkaline digestibility assays were run for six protein sources (from animal and plant origin) using the enzymatic extract from larvae $30 \mathrm{DAH}$. Independent of fish age, all plant feedstuffs reduced alkaline digestive proteases activity; however, the wheat flour $(14.1 \%$ at $6 \mathrm{DAH}$, $33.4 \%$ at $15 \mathrm{DAH})$ and broken rice meal $(51.6 \%$ at $22 \mathrm{DAH}$ ) showed the lowest inhibition percentage of alkaline digestive activity, whereas the highest inhibition percentage was found with soybean and palm
\end{abstract}

S. Valverde-Chavarría $\cdot$ M. Brais-Medina .

E. Calvo-Elizondo · J. B. Ulloa-Rojas ( $₫)$

Laboratorio de Acuicultura Continental, Escuela de

Ciencias Biológicas, Universidad Nacional,

Heredia 86-3000, Costa Rica

e-mail: juan.ulloa.rojas@una.cr

C. A. Álvarez-González

Laboratorio de Acuacultura, DACBIOL, Universidad

Juárez Autónoma de Tabasco, Carretera Villahermosa

Cárdenas Km 0.5, 86139 Villahermosa, Tabasco, Mexico kernel meals $(92.5 \%$ at 30 DAH and $87.4 \%$, respectively) $(P<0.05)$. The alkaline proteases inhibition percentage of feedstuffs varied during larvae ontogeny. From six protein dietary sources tested, tankage and fish meal presented the highest in vitro digestibility values, 113.9 and $74.9 \%$, respectively. Contrary, the lowest digestibility was found for blood and soybean meals (38.07 and $19.82 \%$, respectively).

Keywords Parachromis dovii . Fish larvae . Digestive proteases inhibitor · In vitro digestibility

\section{Introduction}

Parachromis dovii is the biggest freshwater native Central America cichlid, a piscivorous fish, and due to its strength and good flavor, it is very popular for sports fishing and as a good protein source in rural areas (Bussing 2002). According to our observations, it also shows good traits for aquaculture such as spontaneous reproduction in captivity, high resistance to management and diseases and early acceptance of inert diets.

As other freshwater fish species, P. dovii spawns big eggs, its larvae contain a high amount of yolk reserves and the stomach develops earlier than in marine species (Lazo et al. 2011), facilitating the consumption of inert diets from the beginning of its exogenous feeding. 
Despite this, its growth when fed inert diets is still lower compared to that achieved with live food (Artemia nauplii) (Quirós et al. 2014). According to Lazo (2000), among the reasons that have been postulated on the poor performance of formulated diets are: lack of substances that stimulate their ingestion; they do not stimulate the secretion of zymogens into the digestive tract, or inhibit certain digestive enzymes already present; they are deficient in essential nutrients (such as amino acids, fatty acids and vitamins); they provide essential nutrients but with inadequate chemical structure for digestion, absorption and efficient use, or in improper proportions. Because of this, the evaluation of larvae digestive capacity during ontogeny as well as the determination of their nutritional requirements is needed (Álvarez-González et al. 2008; Lazo et al. 2011).

Diet digestibility is very important because the digestive system develops during the larval phase. Because of the high protein requirement during this phase, and the economic cost of high protein sources, it is advisable to evaluate the quality of the protein (Lazo 2000; Martínez-Montaño and Lazo 2012).

Because of the increasing prices of fish meal, main protein source in aquafeeds, there is a trend to use alternatives protein sources to partially replace it. Some of these feedstuffs are from plant origin, which are constrained by the presence of antinutritional factors such as inhibitors of digestive proteases, affecting the organism digestive process (Alarcón et al. 2001). The in vitro tests of digestibility and enzymatic inhibition are easy and fast tools to evaluate the bioavailability of feedstuffs (Alarcón et al. 2001, 2002; Chong et al. 2002). Due to changes in the digestive capacity of larvae, it is recommended to apply these tools during larvae ontogeny to select the adequate feedstuffs to formulate highly digestible diets for different larval stages (Martínez-Montaño and Lazo 2012).

To improve the performance of formulated diets for larvae and early juvenile of $P$. dovii, the objective of this study was to evaluate different feedstuffs as potential dietary ingredients. This was based on the in vitro digestibility comparison of six protein sources (from animal and plant origin) and the quantification of the in vitro inhibitory effect of seven plant ingredients on the protease activity. Our hypothesis was that soybean meal has a lower digestibility than animal meals and plants ingredients cause different levels of proteases inhibition in dependence of the larvae age. Digestibility and inhibition tests were done using alkaline proteases because of their high contribution to protein hydrolysis during the larval phase (Moyano 2013) and because plant inhibitors affecting fish gastric proteases have not been reported, whereas inhibitors of pancreatic digestive proteases are widely distributed among seed plants (Alarcón et al. 2001).

\section{Materials and methods}

Reproduction and larvae culture

The reproduction and larvae rearing were done at the hatchery unit of the Escuela de Ciencias Biológicas of Universidad Nacional de Costa Rica. The broodstock of $P$. dovii (1 male: 1 female) was maintained in $2 \mathrm{TM}$ tanks with a water recirculation system, a temperature around $25^{\circ} \mathrm{C}$ and a photoperiod of $9 \mathrm{~h}$ light: $15 \mathrm{~h}$ dark. The spawners were fed with a commercial trout feed three times per day $(9,13$ and 17 h). P. dovii larvae were obtained from spontaneous spawns (500-1000 larvae each).

After hatching, all larvae were transferred and randomly distributed into the aquaria (11 1 each, 23 larvae $1^{-1}$ ) of a recirculation system until the end of the experiment. The water temperature was kept at 25-29 ${ }^{\circ} \mathrm{C}$, dissolved oxygen at 6.0-6.5 ppm and $\mathrm{NH}_{3}$ at $0.05 \mathrm{ppm}$ maximum. The photoperiod was kept as in the spawner's tanks. Larvae were fed in excess of Artemia nauplii and metanauplii (about $250 \mathrm{ml}^{-1}$ ) from 5 DAH to 30 DAH. Before feeding, all feed and feces wastes remaining were removed from the bottom of the aquaria and during feeding the water flow was stopped for $30 \mathrm{~min}$ to avoid feed losses.

Larvae sampling and biometrics

Twenty larvae were sampled at 6, 15, 22, $30 \mathrm{DAH}$ before the initial feeding and kept $2 \mathrm{~h}$ in clear water to allow the emptiness of digestive tract. Next, they were killed with an overdose of tricaine methanesulfonate (MS-222), measured with a stereoscopy (Olympus 329345 with ocular micrometer: $\pm 0.07 \mathrm{~mm}$ ) or vernier $( \pm 0.01 \mathrm{~mm})$ and weighted with an analytical balance (Sartorius $2492 \pm 0.1 \mathrm{mg}$ ). Finally, larvae were washed with distilled water and kept frozen at $-20{ }^{\circ} \mathrm{C}$ for further biochemical analysis. 
Preparation of enzymatic extracts and determination of alkaline enzymatic activity

The enzymatic extracts were prepared according to Alarcón et al. (2001). Briefly, the frozen larvae were lyophilized, and then, the viscera bulk was removed from each larva by cutting off the tail, head and dorsal part of the body. Samples from the smallest larvae were taken by removing their head and tail. Then samples of each larvae stage were homogenized with deionized water in a proportion of $30 \mathrm{mg}$ tissues $/ \mathrm{ml}$ water using a tissue homogenizer (Contes). Next, the homogenized sample was centrifuged at $16,000 \mathrm{~g}, 4{ }^{\circ} \mathrm{C}$ for $30 \mathrm{~min}$ (Hettich Mikro 200). The supernatant was kept at $-20{ }^{\circ} \mathrm{C}$ for further enzymatic analysis.

The measurement of total alkaline proteolytic activity was done according to Walter (1984), incubating the enzymatic extract with $0.5 \%$ casein at $\mathrm{pH}$ 9.0 and $37{ }^{\circ} \mathrm{C}$. One unit of enzymatic activity was defined as $1 \mu \mathrm{g}$ tyrosine released $\min ^{-1}$, using the tyrosine 0.005 molar extinction coefficient. All determinations were done in triplicate, and the enzymatic activity was calculated as:

Activity per ml: $\mathrm{U} \mathrm{ml}^{-1}=\frac{\Delta \text { absorbance } \times \mathrm{FD}(\mathrm{ml})}{\text { MEC tyrosine } \times T(\mathrm{~min})}$

Total activity (per individual): $\mathrm{U} \mathrm{larvae}^{-1}=\left(\mathrm{U} \mathrm{ml}^{-1}\right) / \mathrm{N}$

Specific activity: $\mathrm{U} \mathrm{mg} \mathrm{P}^{-1}=\frac{\mathrm{U} \mathrm{ml}^{-1}}{\mathrm{mg} \mathrm{P} / \mathrm{ml}}$ where U: enzymatic activity units, $\Delta$ absorbance: increment in absorbance respect to blank at $280 \mathrm{~nm}$; FD: final volume of enzymatic extract reaction/extract volume; MEC: tyrosine molar extinction coefficient; $T$ : incubation time $(\mathrm{min}) ; N$ : number of larvae per milliliter of enzymatic extract; mg P: mg of soluble protein in extract.

The soluble protein concentration was determined by Bradford (1976) using serum bovine albumin as standard.

Inhibitory effect of some plant meals on alkaline digestive proteases

For this test, larvae were obtained from spontaneous spawns of hybrid females (ô $P$. dovii $\times+P$. managuensis) $\times \hat{\sigma} P$. dovii since pure females were not available at the moment of the study. These hybrid females showed similar phenotypical traits and comparable weight and size to $P$. dovii ones. Larvae samples were taken at 6,15, 22 and $30 \mathrm{DAH}$ and the enzymatic extract prepared as previously described, except for the homogenized which was prepared using deionized water instead of buffer. Total alkaline proteolytic activity was calculated as in the previous section.

Seven plant ingredients were selected according to their nutritional value and local availability: soybean meal (solvent extract), wheat middlings and shorts, corn powder, broken rice, oil palm kernel meal, rice bran and polishing, and wheat powder (Table 1).
Table 1 Proximal composition (\% dry matter) of feedstuffs evaluated in the in vitro digestibility and inhibition tests. Mean $\pm \mathrm{SD}, n=3$

NFE nitrogen-free extract

\begin{tabular}{lrrrr}
\hline Ingredients (meals) & \multicolumn{1}{l}{ Protein } & Lipid & NFE & \multicolumn{1}{l}{ Ash } \\
\hline In vitro digestibility & & & & \\
$\quad$ Fish (Panama) & $64.83 \pm 1.85$ & $14.13 \pm 0.01$ & 0.26 & $20.78 \pm 0.01$ \\
$\quad$ Tuna by-products & $58.83 \pm 0.12$ & $10.51 \pm 0.16$ & 6.25 & $24.41 \pm 0.10$ \\
Poultry by-products & $51.51 \pm 0.44$ & $35.28 \pm 0.52$ & 0.9 & $12.31 \pm 0.11$ \\
Tankage & $39.48 \pm 1.20$ & $19.67 \pm 0.52$ & 4.74 & $36.11 \pm 0.67$ \\
Blood & $89.60 \pm 0.60$ & $1.29 \pm 0.11$ & 0.04 & $9.07 \pm 0.11$ \\
Soybean (solvent extract) & $55.10 \pm 0.01$ & $3.96 \pm 0.10$ & 33.82 & $7.12 \pm 0.03$ \\
Inhibitory effect & & & & \\
Wheat middlings and shorts & $19.38 \pm 075$ & $7.78 \pm 0.53$ & 67.26 & $5.58 \pm 0.01$ \\
Corn flour & $11.65 \pm 0.32$ & $9.11 \pm 0.42$ & 76.07 & $3.17 \pm 0.02$ \\
Broken rice & $9.76 \pm 0.13$ & $4.32 \pm 0.09$ & 84.96 & $0.97 \pm 0.02$ \\
Oil palm kernel & $15.28 \pm 0.48$ & $10.33 \pm 0.37$ & 70.17 & $4.23 \pm 0.05$ \\
Rice bran and polishing & $13.86 \pm 0.27$ & $12.05 \pm 0.40$ & 62.26 & $11.83 \pm 0.52$ \\
Wheat flour & $12.50 \pm 0.61$ & $6.88 \pm 0.32$ & 79.55 & $1.06 \pm 0.01$ \\
\hline
\end{tabular}


Meals extracts were prepared according to Alarcón et al. (2001) with some modifications. Each meal was ground and sieved to a final particle size of $150 \mu \mathrm{m}$, and $1 \mathrm{~g}$ of each meal (dry weight) was dissolved in deionized water to a final volume of $10 \mathrm{ml}$ (concentration of $10 \% \mathrm{w} / \mathrm{v}$ ). The solution was kept in a water bath with moderate shaking for $2 \mathrm{~h}$ at room temperature, followed by $22 \mathrm{~h}$ at $4{ }^{\circ} \mathrm{C}$. After this period, the solution was centrifuged at $16,000 \mathrm{~g}$ for $30 \mathrm{~min}$ at $4^{\circ} \mathrm{C}$. The recovered supernatant was kept at $-20{ }^{\circ} \mathrm{C}$ until used.

The inhibition percentage of the alkaline proteolytic activity by the meals was quantified as in García-Carreño et al. (1996). Briefly, for each activity unit (AU) of total alkaline proteases present in a volume of $20 \mu \mathrm{l}$ of enzymatic extract $500 \mu \mathrm{g}$ of meal extract were added and buffer $\mathrm{pH}$ 9.0. This mixture was incubated at room temperature for $60 \mathrm{~min}$, and then the residual proteolytic activity was measured after adding casein $0.5 \%$ and incubating the mixture for $45 \mathrm{~min}$ at $37^{\circ} \mathrm{C}$. The reaction was stopped with trichloroacetic acid (TCA) $20 \%$ and centrifuged at $16,000 \mathrm{~g}$ for $5 \mathrm{~min}$. The absorbance of the supernatant was read at $280 \mathrm{~nm}$. For the blanks, the TCA was added together with the casein. For the activity controls, the meal was substituted by deionized water. All determinations were done in triplicate.

The inhibition percentage (\% I) was defined as the percent reduction in enzymatic activity (calculated as in the previous section) compared to the activity control (without inhibitor).

$\% I=100$

$$
-((\Delta \text { Abs feedstuff } / \Delta \text { Abs Control }) * 100),
$$

where $\Delta$ Abs: the increment in absorbance respect to blank.

In vitro alkaline digestibility of several ingredient protein sources

The in vitro digestibility was determined for six meals using 30-day-old $P$. dovii juveniles. The enzymatic extracts were prepared using a $1: 5 \mathrm{~W}: \mathrm{V}$ proportion (visceral weight: deionized water volume) and their alkaline proteolytic activity quantified as described previously. The ingredients evaluated, selected according to their protein content, price and local availability, were: fish (from Panamá), tuna (from by- products), soybean, poultry (by-products), blood and tankage meals (Table 1). All meals were ground to a particle size of $75 \mu \mathrm{m}$.

The in vitro protein digestibility of meals was determined using the pH-STAT technique, according to Dimes and Haard (1994). Briefly, an ingredient sample corresponding to $40 \mathrm{mg}$ protein was mixed in distilled water for $15 \mathrm{~min}$, adjusting $\mathrm{pH}$ at 8.0. Next, an enzymatic extract amount, equivalent to $12 \mathrm{AU}$ of total alkaline proteases, was added keeping $\mathrm{pH}$ at 8.0. The final volume was adjusted to $5 \mathrm{ml}$ with distilled water. Titration time was $45 \mathrm{~min}$, with continuous mixing at room temperature (about $25^{\circ} \mathrm{C}$ ), using an automatic titrator 906 Titrando (Metrohm Ltd, Switzerland).

The degree of protein hydrolysis (DH) was calculated according to Adler-Nissen (1986):

$\mathrm{DH}=B \times N_{\mathrm{B}} \times 1 / \alpha \times 1 / M_{\mathrm{P}} \times 1 / h_{\mathrm{tot}} \times 100 \%$

where $B: \mathrm{NaOH}$ volume (ml) used for keeping $\mathrm{pH}$ at 8.0 during the reaction time; $N_{\mathrm{B}}$ : normality of the alkaline $(0.1 \mathrm{~N}) ; \alpha$ : mean dissociation grade of $\alpha$ amino acids released during hydrolysis, according to Adler-Nissen (1986), at $\mathrm{pH} 8.0$ and reaction temperature around $25^{\circ} \mathrm{C}$ is $1 \alpha^{-1}=1.5 ; \mathrm{M}_{\mathrm{P}}$ : crude protein mass in the reaction mixture, calculated by multiply nitrogen concentration $(N)$ obtained with Kjeldahl method (1883) per an adequate conversion factor $\left(\mathrm{f}_{\mathrm{N}}\right)$; $\mathrm{h}_{\text {tot }}$ : total content of protein peptide bonds, expressed as equivalents to peptide bonds per kilogram (or milliequivalents per gram), with $8.0 \mathrm{meq}^{-1}$ as a good approximation (Adler-Nissen 1986).

Determinations were done in triplicate and base lines by duplicate. Casein was used as reference protein with a DH of 100 , and as a result, to each ingredient it was assigned a proportional digestibility value related to that of casein.

Statistical analysis

To determine differences in growth, enzymatic activity and digestibility, the mean values of data were analyzed by applying a one-way ANOVA. The homogeneity of variances and the normal distribution were tested according to the Levene and Shapiro-Wilk tests. Treatment means comparison was done using the LSD test with $95 \%$ confidence intervals. All analyses were realized using the software Statgraphics Centurion XVI (StatPoint Technologies Inc., 2010). 


\section{Results}

Fish Growth

At the beginning of the exogenous feeding, the larvae weight and length were $4.73 \pm 0.08 \mathrm{mg}$ and $8.53 \pm 0.06 \mathrm{~mm}$, respectively. After 30 days of culture (30 DAH), fingerlings had a weight and length 24.6 and 2.4 times higher than the initial values, respectively (Fig. 1).

Larvae presented an exponential growth for weight $\left(W=2.282 \mathrm{e}^{0.131(\mathrm{DAH})}, \quad r^{2}=0.996\right) \quad$ and length $\left(L=6.852 \mathrm{e}^{0.035(\mathrm{DAH})}, r^{2}=0.989\right)$, showing differences between larvae age $(P<0.05)$.

\section{Alkaline enzymatic activity}

Enzymatic activity was detected from the beginning of exogenous feeding at $6 \mathrm{DAH}$. The specific alkaline activity fluctuated along larvae development, showing a reduction at $22 \mathrm{DAH}$, whereas total alkaline proteolytic activity increased with culture time from $0.11 \pm 0.00$ to $5.58 \pm 0.06 \mathrm{U}$ larvae $^{-1}$ at $30 \mathrm{DAH}$ (about 51 times more). The specific proteolytic activity showed a similar pattern (Table 2).

Inhibitory effect of some vegetable meals on alkaline digestive proteases

All plant meals reduced the alkaline proteolytic activity of $P$. dovii hybrid larvae. The soybean and wheat middlings and shorts showed the highest inhibition percentages (92.5 and $89.5 \%$, respectively),

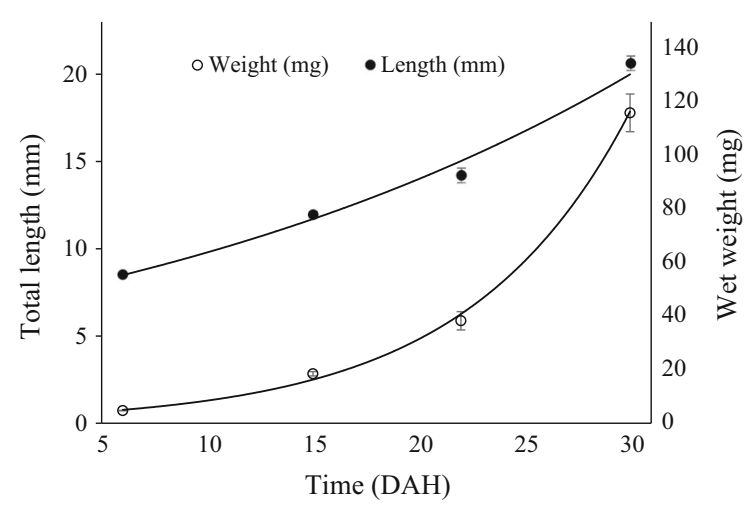

Fig. 1 Wet weight and total length of $P$. dovii hybrid larvae used for the inhibitory test (mean $\pm \mathrm{SD}, n=20$ ) whereas wheat flour $(14.1 \%)$ and broken rice meal $(23.3 \%)$ had the lowest values (Fig. 2; Table 3, $P<0.05)$.

Further, differences between fish stages were detected, e.g., 30 DAH fingerlings were more sensible to proteases inhibitors present in most meals, except for soybean, oil palm kernel and wheat middlings and shorts. The highest inhibition percentages were detected for corn and soybean meals (Fig. 3; Table 3, $P<0.05)$.

In vitro alkaline protein's digestibility of several ingredients

The weight and length of juvenile used were $164 \pm 23 \mathrm{mg}$ and $23.48 \pm 1.04 \mathrm{~mm}$, respectively. The total and specific alkaline proteolytic activities were $5.4 \mathrm{U}$ larvae ${ }^{-1}$ and $26.4 \mathrm{U} \mathrm{mg}^{-1}$ soluble protein, respectively, whereas the proteolytic activity per volume was $44.08 \mathrm{U} \mathrm{mL}^{-1}$.

All ingredients increased their degree of protein hydrolysis along time. Tankage showed the highest increment in final degree of hydrolysis (3.04) and in vitro protein alkaline digestibility (113.92\%), even more than casein. Next, it was followed by Panama fish meal $(2.0$ and $74.92 \%)$ and poultry by-products (1.87 and $69.99 \%)$. Contrary, blood (1.01 and $38.07 \%)$ and soybean (0.53 and $19.82 \%)$ meals had the lowest values for the same variables (Table 4; Fig. 4).

\section{Discussion}

\section{Growth}

Yolk reserves of $P$. dovii larvae last a few more days after exogenous feeding and they present a stomach with gastric glands at the time of the first feeding (6 DAH) (Valverde-Chavarría et al. 2013), similarly to Petenia splendida larvae (Treviño et al. 2011). According to Gisbert and Williot (1997), large yolk reserves in fish larvae could facilitate the transition to exogenous feeding and be advantageous for any delay in transition.

The larvae growth was slightly lower to that found by Quirós et al. (2014) with P. dovii larvae (at 15 DAH), which may be attributed to the effect of the lower culture density used by the latter author, as 
Table 2 Alkaline proteolytic activity in enzymatic extracts of $P$. dovii hybrid larvae

\begin{tabular}{lllll}
\hline Parameter/larvae age & $6 \mathrm{DAH}$ & $15 \mathrm{DAH}$ & $22 \mathrm{DAH}$ & 30 DAH \\
\hline Proteolytic activity $\left(\mathrm{U} \mathrm{ml}^{-1}\right)$ & $5.28 \pm 0.16^{\mathrm{a}}$ & $18.3 \pm 0.28^{\mathrm{b}}$ & $12.3 \pm 0.19^{\mathrm{c}}$ & $33.3 \pm 0.38^{\mathrm{d}}$ \\
Total proteolytic activity $(\mathrm{U}$ larvae & & \\
Specific proteolytic activity $\left(\mathrm{U} \mathrm{mg} \mathrm{P}^{-1}\right)$ & $0.11 \pm 0.00^{\mathrm{a}}$ & $0.80 \pm 0.01^{\mathrm{b}}$ & $1.43 \pm 0.03^{\mathrm{c}}$ & $5.58 \pm 0.06^{\mathrm{d}}$ \\
\hline
\end{tabular}

Mean \pm SE, $n=3$. Different letters in the same row mean significant differences $(P<0.05)$

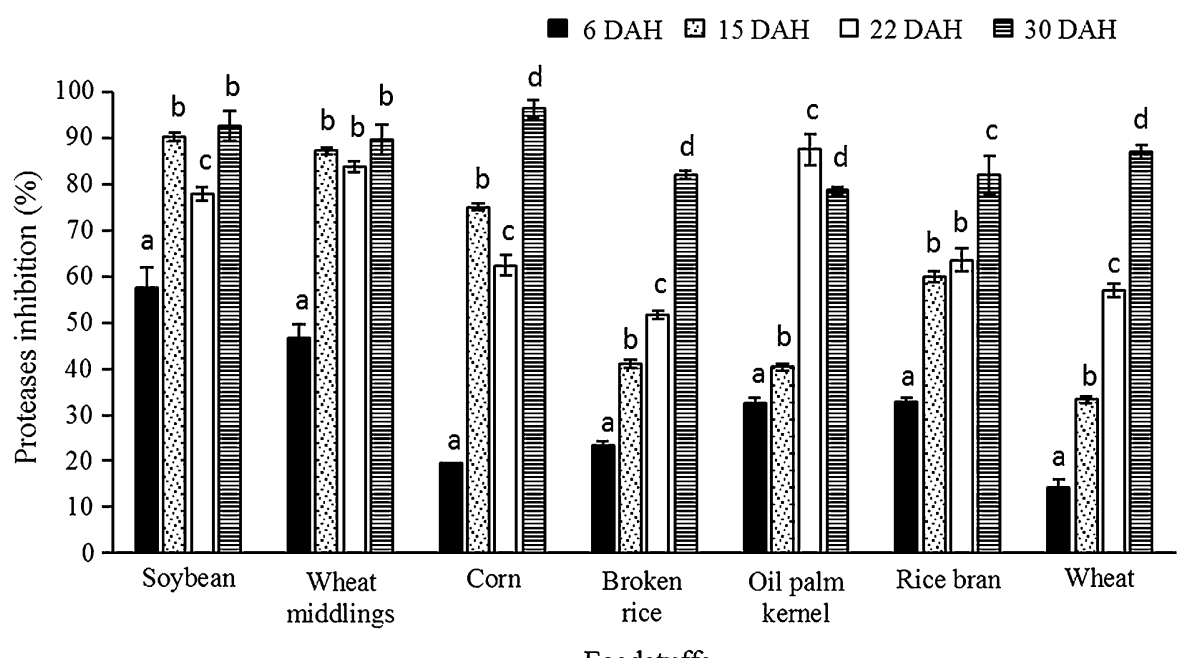

Fig. 2 Inhibition percentage (\%) of alkaline digestive proteases for several plant feedstuffs tested with $P$. dovii hybrid larvae of $6,15,22$ and $30 \mathrm{DAH}$ (mean $\pm \mathrm{SD}$ ). Means with different

letters for each meal indicated significant difference between larvae stages $(P<0.05)$

Table 3 Inhibition percentage (\%) of alkaline digestive proteases in $P$. dovii hybrid larvae of 6, 15, 22 and 30 DAH (mean \pm SE, $n=3$ ) using several plant feedstuffs

\begin{tabular}{llllllll}
\hline DAH & Plant feedstuffs & & & & \\
\cline { 2 - 7 } & Soybean & Wheat middlings & Corn & Broken rice & Oil palm kernel & Rice bran & Wheat \\
\hline 6 & $57.61 \pm 4.34^{\mathrm{e}}$ & $46.74 \pm 2.87^{\mathrm{d}}$ & $19.57 \pm 0.00^{\mathrm{ab}}$ & $23.28 \pm 0.86^{\mathrm{b}}$ & $32.61 \pm 1.09^{\mathrm{c}}$ & $32.75 \pm 0.86^{\mathrm{c}}$ & $14.13 \pm 1.88^{\mathrm{a}}$ \\
15 & $90.15 \pm 0.76^{\mathrm{f}}$ & $87.12 \pm 0.76^{\mathrm{e}}$ & $74.95 \pm 0.74^{\mathrm{d}}$ & $41.07 \pm 0.74^{\mathrm{b}}$ & $40.33 \pm 0.74^{\mathrm{b}}$ & $59.85 \pm 1.31^{\mathrm{c}}$ & $33.34 \pm 0.76^{\mathrm{a}}$ \\
22 & $77.69 \pm 1.48^{\mathrm{d}}$ & $83.65 \pm 1.26^{\mathrm{e}}$ & $62.26 \pm 2.18^{\mathrm{bc}}$ & $51.57 \pm 1.26^{\mathrm{a}}$ & $87.42 \pm 3.33^{\mathrm{e}}$ & $63.52 \pm 2.52^{\mathrm{c}}$ & $56.88 \pm 1.49^{\mathrm{ab}}$ \\
30 & $92.47 \pm 3.32^{\mathrm{cd}}$ & $89.54 \pm 3.27^{\mathrm{bcd}}$ & $96.23 \pm 1.92^{\mathrm{d}}$ & $81.99 \pm 0.00^{\mathrm{ab}}$ & $78.56 \pm 0.86^{\mathrm{a}}$ & $81.99 \pm 4.13^{\mathrm{ab}}$ & $87.03 \pm 1.51^{\mathrm{bc}}$ \\
\hline
\end{tabular}

Means with different letters in the same indicated significant difference between feedstuffs type $(P<0.05)$

proved with pikeperch larvae (Sander lucioperca L.) by Szkudlarek and Zakęś (2007).

\section{Alkaline proteolytic activity}

The presence of alkaline proteolytic activity since the beginning of exogenous feeding has been also observed in larvae of Clarias gariepinus (GarcíaOrtega et al. 2000), Oreochromis niloticus (Tengjaroenkul et al. 2002), O. mossambicus (Lo and Weng 2006), Cichlasoma urophthalmus (LópezRamírez et al. 2011), Petenia splendida (UscangaMartínez et al. 2011) and Cichlasoma trimaculatum (Toledo-Solís et al. 2015). These enzymes are the 


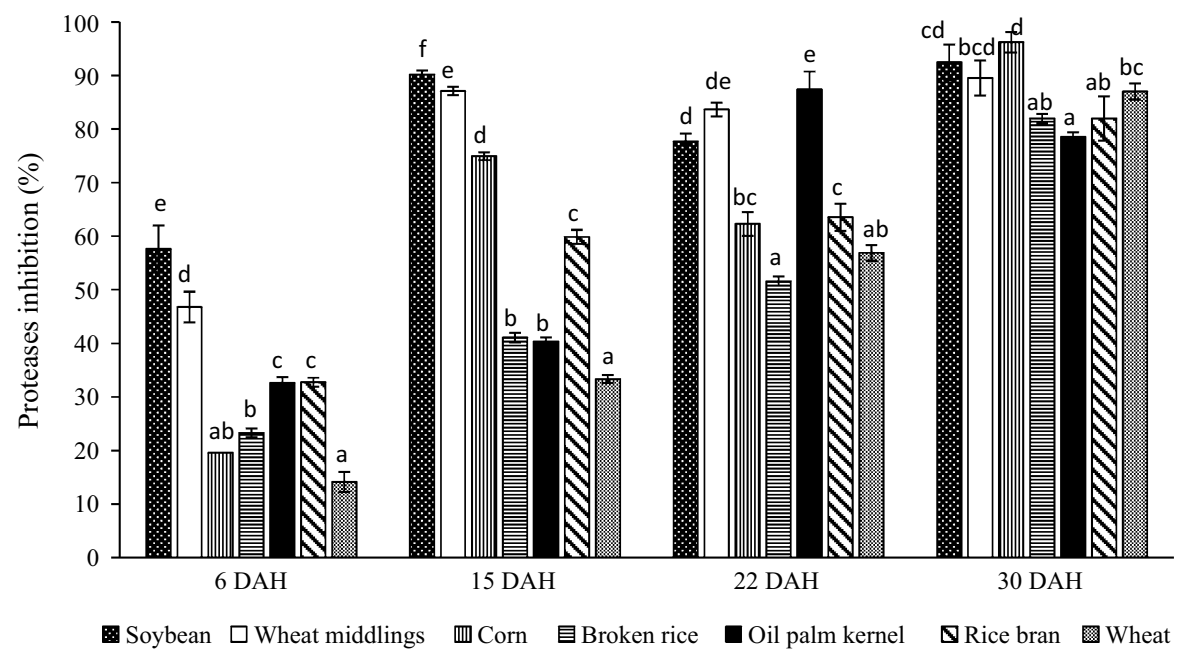

Fig. 3 Inhibition percentage (\%) of alkaline digestive proteases in $P$. dovii hybrid larvae of 6, 15, 22 and $30 \mathrm{DAH}$ (mean $\pm \mathrm{SD}$ ) using several feedstuffs. Means with different letters for each

Table 4 Degree of alkaline protein hydrolysis (DH) and alkaline protein digestibility (\%) for several dietary protein sources with 30-day-old $P$. dovii juvenile

\begin{tabular}{llc}
\hline Ingredients & HG & Digestibility \\
\hline Casein & $2.67 \pm 0.07$ & $100.00 \pm 2.62^{\mathrm{a}}$ \\
Tankage & $3.04 \pm 0.17$ & $113.92 \pm 6.17^{\mathrm{b}}$ \\
Fish meal Panama & $2.00 \pm 0.09$ & $74.92 \pm 3.4^{\mathrm{c}}$ \\
Poultry by-products & $1.87 \pm 0.08$ & $69.99 \pm 2.68^{\mathrm{c}}$ \\
Tuna fish meal Costa Rica & $1.41 \pm 0.13$ & $52.85 \pm 4.72^{\mathrm{d}}$ \\
Blood meal & $1.01 \pm 0.06$ & $38.07 \pm 2.03^{\mathrm{e}}$ \\
Soybean meal & $0.53 \pm 0.00$ & $19.82 \pm 0.00^{\mathrm{f}}$ \\
\hline
\end{tabular}

Mean $\pm \mathrm{SD}, n=3$. Means with different letters are significant different $(P<0.05)$

first type to be detected and are capable of acting before the digestive tract completeness (Moyano et al. 1996); their appearance seems to be genetically programmed (Zambonino-Infante and Cahu 2001, Lo and Weng 2006). The increment in the alkaline proteolytic activity from 6 DAH onwards agrees with Quirós et al. (2014) and with the presence of acidophilic granules (zymogens or enzymatic precursors) in the pancreas (Valverde-Chavarría et al. 2013). The sharp increment in proteolytic activity at the end of the larvae stage (approximately at 28 DAH) may be attributable to the complete development of the digestive system and its bigger size (Valverde-Chavarría et al. 2013) hatching period indicate significant difference between feedstuffs type $(P<0.05)$

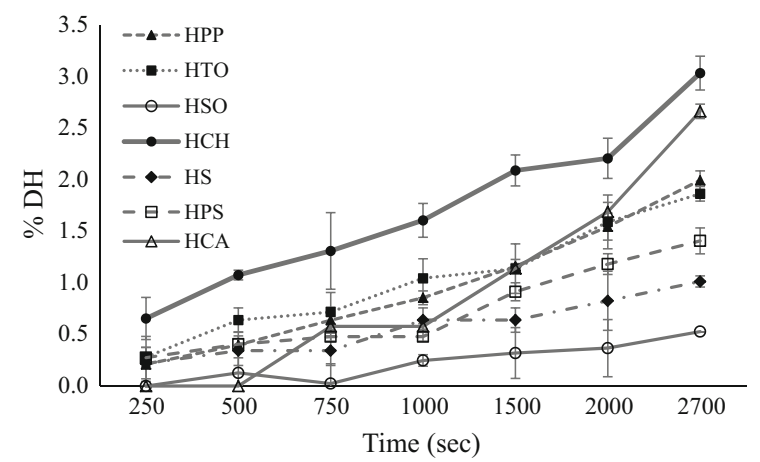

Fig. 4 Degree of alkaline protein hydrolysis $(\% \mathrm{DH})$ in enzymatic extracts of 30-day-old $P$. dovii juveniles with several protein source feedstuffs. Mean $\pm \mathrm{SD}, n=3$. HPP: fish meal Panama, HTO: poultry by-products, HSO: soybean meal, $\mathrm{HCH}$ : tankage, HS: blood meal, HPS: tuna meal Costa Rica and HCA: casein

Inhibitory effect of some plant meals on alkaline digestive proteases

Apart from the nutritional requirements knowledge, in order to formulate diets to maximize the fish larvae growth, it is also recommended to evaluate the quality of different feedstuffs using tools such as in vitro techniques to determine not only (a) the digestive proteases inhibition potential of plant origin feedstuffs but also (b) the protein alkaline digestibility of animal and plant protein sources. These results will help with 
a better selection of dietary ingredients in feed formulations.

The use of plant feedstuffs to replace fish meal in larvae diets has drawn little attention, especially related to its inhibitory effect on larvae alkaline proteases. The inhibitory effect of plant ingredients on the alkaline proteolytic activity of $P$. dovii hybrid larvae was influenced by the larvae stage (Fig. 2), which could be attributed to the temporal changes in the digestive tract and proteases level during ontogeny (Quirós et al. 2014). According to this, it is advised to formulate diets for the different larvae stages taking into consideration those ingredients with lower proteases inhibition and higher digestibility. In some marine and other freshwater fish species, the inhibitory effect of plant meals varied depending on the ingredient type, amount used and species (El-Sayed et al. 2000; Alarcón et al. 2001; Chong et al. 2002; Pérez et al. 2003; Santigosa et al. 2008; Rodiles et al. 2012).

Independent of larvae stage, soybean meal and wheat middlings and shorts showed the highest in vitro proteases inhibition $(P<0.05)$ agreeing with that reported for Piaractus mesopotamicus (Pérez et al. 2003), Lutjanus argentiventris and L. novemfasciatus (Alarcón et al. 2001). The reduction in growth and feed utilization in $O$. niloticus, when substituting dietary fish meal with soybean meal, reported by ElSayed et al. (2000), could be affected by proteases inhibitors present in soybean. Indeed, it is known that soybean possesses proteases inhibitors (such as Kunitz and Bowman-Birk) which exert an effect on specific proteases and also possesses phytates which form indigestible complexes with protein (NRC 2011). Contrary, Chong et al. (2002) detected low enzymatic inhibition for soybean in Symphysodon spp. Wheat meal and their by-products also showed proteases inhibition in other species, such as adults of $O$. niloticus, Sparus aurata and Solea senegalensis (Moyano et al. 1999). Also different to our results, it has been reported that wheat derivatives had lower proteases inhibition than rice by-products (polishing with hulls) in adults of $P$. mesopotamicus and Odontesthes bonaeriensis (Pérez et al. 2003).

Similar to our findings, corn meal has shown an inhibitory effect on alkaline proteases (specifically on trypsin) (Jamal et al. 2012). As proteases inhibitors were detected in kernel oil palm meal (KOPM), their presence may explain partly the growth reduction found with $O$. aureus when fed KOPM at $10 \%$ or higher levels (Iluyemi et al. 2010). However, bioconversion processes such as fermentation with Trichoderma koningii has improved the protein digestibility of KOPM in tilapia hybrids ( $\mathrm{Ng}$ et al. 2002; Hem et al. 2008). In order to improve the nutritional quality of feedstuffs, it has been suggested also thermic treatments to inactivate to some extent these proteases inhibitors (Alarcón et al. 2001).

At different larvae stages, the inhibitory effect of the plant ingredients tested seem to be related to the development of the digestive system and alkaline proteases level. According to this, at $6 \mathrm{DAH}$, the inhibition rates are lower compared to those obtained at $30 \mathrm{DAH}$, when the digestive system is complete and of bigger size. These differences in results suggest an apparent effect on inhibition of feedstuffs type, processing and species, especially when comparing data from different fish ages.

In vitro alkaline protein's digestibility of several ingredients

In relation to the in vitro alkaline protein digestibility, our results with $P$. dovii fingerlings (30 days old) agree with those found by Álvarez-González et al. (2008) with juveniles of another carnivorous cichlid, Petenia splendida. They obtained low digestibility values for soybean and blood meals and high values for casein, poultry by-products and fish meals. Similar results were also found with other carnivorous fishes, Centropomus undecimalis (Concha-Frías 2008) and Sparus aurata juveniles (Alarcón et al. 2002). In these works, casein, fish meal and tankage showed the highest values and blood and soybean meals the lowest.

According to Uscanga-Martínez et al. (2011), the digestibility of different protein sources is related to the fish feeding habits, having the carnivorous fish higher capacity to hydrolyze meals from animal origin. These could explain the higher in vitro digestibility values obtained for most animal ingredients showed by $P$. dovii juvenile. It is possible that the higher hydrolysis values obtained with tankage and Panama fish meal (whole fish) were derived from a higher proportion and accessibility of basic (arginine and lysine) and aromatic amino acids (phenylalanine, tyrosine, tryptophan) from these ingredients, facilitating the proteolytic activity.

Despite that tankage presented the highest digestibility, it contains an imbalance amino acid 
profile when compared to fish meal, concluding that both criteria must be taking in consideration for ingredient selection. The low digestibility of blood meal could be related to its imbalance amino acid profile and high iron level, which could interfere with the digestive process and in consequence with fish growth, agreeing with Álvarez-González (2003). Additionally, lower digestibility values presented by plant origin protein source (soybean meal) may be related to its content of proteases inhibitors and other antinutritional factors (Martínez-Montaño and Lazo 2012).

Based on these results, new studies may be planned to substitute fish meal (partly or completely) with poultry by-products or tankage in diets for $P$. dovii larvae or fingerlings, taking in consideration the aa's profile of these meals.

In conclusion, alkaline proteases from $P$. dovii larvae and fingerlings were inhibited at different levels for all the plant feedstuffs evaluated. $P$. dovii juveniles presented a higher in vitro protein digestibility for most animal protein ingredients evaluated, in contrast to plant protein sources (e.g., soybean meal). It is advisable to validate these results in vivo, to test other ingredients and use enzymatic extracts from distinct stages of the life cycle of $P$. dovii in order to formulate adequate diets according to the digestive capability of different fish stages.

Acknowledgments This research was supported by the projects SIA 0021-07 "PS Tecnología Acuicultural" and SIA 0315-10 "Desarrollo de una dieta inerte para larvas del guapote lagunero Parachromis dovii (Pisces Cichlidae) formulada de acuerdo con su capacidad digestiva y requerimientos proteicos" of the Escuela de Ciencias Biológicas, Universidad Nacional. Thanks to the MSc. Cristian Fonseca R., from the laboratory of Fisheries Product Quality of the Marine Biology Station, for the proximal analyses of ingredients.

\section{Compliance with ethical standards}

Conflict of interest The authors declare that they have no conflict of interest.

Statement on welfare of animals Animals were manipulated adequately according to good welfare practices.

\section{References}

Adler-Nissen J (1986) Enzymic hydrolysis of food proteins. Elsevier Applied Science Publishers, London
Alarcón F, García-Carreño F, Navarrete del Toro M (2001) Effect of plant protease inhibitors on digestive proteases in two fish species, Lutjanus argentiventris and L. novemfasciatus. Fish Physiol Biochem 24:179-189

Alarcón F, Moyano F, Díaz M (2002) Evaluation of different protein sources for aquafeeds by an optimized $\mathrm{pH}$-stat system. J Sci Food Agric 82:1-8

Álvarez-González C (2003) Actividad Enzimática Digestiva y Evaluación de Dietas para el Destete de Larvas de Cabrilla Arenera Paralabrax maculatofasciatus (Percoidei: Serranidae). Tesis para obtener el grado de Doctor en Ciencias Marinas. La Paz, Baja California Sur, México

Álvarez-González C, Márquez-Couturier G, Arias-Rodríguez L et al (2008) Avances en la fisiología digestiva y nutrición de la mojarra tenguayaca Petenia splendida. En: Cruz Suárez L, Ricque Marie D, Tapia Salazar M, Nieto López M, Villarreal Cavazos D, Lazo Corvea J, Viana M (eds) Avances en Nutrición Acuícola IX. Memorias del Noveno Simposium Internacional de Nutrición Acuícola. Monterrey, N.L. México, pp 135-235

Bradford MM (1976) A rapid and sensitive method for the quantization of microgram quantities of protein utilizing the principle of protein-dye binding. Anal Biochem 72:248-254

Bussing W (2002) Peces de las Aguas Continentales de Costa Rica. Editorial de la Universidad de Costa Rica, San José

Chong A, Hashim R, Ali A (2002) Inhibition of protease activities in discus Symphysodon spp. by three plant meals. Aquacult Int 10:433-441

Concha-Frías B (2008) Evaluación de la capacidad digestiva de juveniles de Centropomus undecimalis (Bloch, 1792), sobre diferentes ingredientes proteínicos. Tesis de Maestría. Universidad Católica del Norte, Chile

Dimes L, Haard N (1994) Estimation of protein digestibility: development of an in vitro method for estimating protein digestibility in salmonids (Salmo gairdneri). Comp Biochem Physiol 108A:349-362

El-Sayed A, Martínez I, Moyano F (2000) Assessment of the effect of plant inhibitors on digestive proteases of Nile tilapia using in vitro assays. Aquacult Int 8:403-415

García-Carreño F, Navarrete del Toro M, Díaz-López M, Hernández-Cortes M, Ezquerra J (1996) Proteinase inhibition of fish muscle enzymes using legume seed extracts. J Food Protec 59:312-318

García-Ortega A, Verreth J, Segner H (2000) Post-prandial protease activity in the digestive tract of African catfish Clarias gariepinus larvae fed decapsulated cysts of Artemia. Fish Physiol Biochem 22(3):237-244

Gisbert E, Williot P (1997) Larval behaviour and effect of the timing of initial feeding on growth and survival of Siberian sturgeon larvae under small scale hatchery production. Aquaculture 156:63-76

Hem S, Toure S, Sagbla C, Legendre M (2008) Bioconversion of palm kernel meal for aquaculture. Experiences from the forest region (Republic of Guinea). Afr J Biotechnol 7:1192-1198

Iluyemi F, Hanafi M, Radziah O, Kamarudin M (2010) Nutritional evaluation of fermented palm kernel cake using red tilapia. Afr J Biotechnol 9:502-507

Jamal F, Pandey P, Singh D, Khan M (2012) Serine protease inhibitors in plants: nature's arsenal crafted for insect predators. Phytochem Rev 12:1-34 
Kjeldahl C (1883) New method for determination of nitrogen in organic materials. Z Anal Chem 22:366-382

Lazo J (2000) Conocimiento actual y nuevas perspectivas en el desarrollo de dietas para larvas de peces marinos. En: CruzSuárez L, Ricque-Marie D, Tapia-Salazar M, OlveraNovoa M, Civera-Cerecedo R (eds) Avances en Nutrición Acuícola V. Memorias del V Simposium Internacional de Nutrición Acuícola. Mérida, Yucatán, pp 300-312

Lazo J, Darias M, Gisbert E (2011) Ontogeny of the digestive tract. In: Holt G (ed) Larval fish nutrition. Wiley, London, pp $1-46$

Lo M, Weng C (2006) Developmental regulation of gastric pepsin and pancreatic serine protease in larvae of the euryhaline Oreochromis mossambicus. Aquaculture 261:1403-1412

López-Ramírez G, Cuenca-Soria C, Álvarez-González C et al (2011) Development of digestive enzymes in larvae of Mayan cichlid Cichlasoma urophthalmus. Fish Physiol Biochem 37(1):197-208

Martínez-Montaño E, Lazo J (2012) In vitro protein digestibility of dietary ingredients throughout ontogeny of California halibut, Paralichtys californicus, larvae. J World Aquacult Soc 43:51-62

Moyano F (2013) Modelizando el Biorreactor; o cómo Conocer Mejor el Digestivo de sus Peces. En: Cruz L, Ricque D, Tapia M, Nieto M, Villareal D, Gamboa J, Álvarez-González C (eds) Contribuciones Recientes en Alimentación y Nutrición Acuícola. 20-22 de Noviembre. Monterrey, Nuevo León, pp 354-373

Moyano F, Díaz M, Alarcón F, Sarasquete M (1996) Characterization of digestive enzyme activity during larval development of gilthead seabream (Sparus aurata). Fish Physiol Biochem 15(2):121-130

Moyano F, Martínez I, Díaz M, Alarcón F (1999) Inhibition of digestive proteases by plant meals in three fish species; seabream (Sparus aurata), tilapia (Oreochromis niloticus) and African sole (Solea senegalensis). Comp Biochem Physiol 122:327-332

$\mathrm{Ng} \mathrm{W}$, Lim H, Lim S, Ibrahim C (2002) Nutritive value of palm kernel meal pretreated with enzyme or fermented with Trichodema koningii (Oudemans) as a dietary ingredient for red hybrid tilapia (Oreochromis sp.). Aquac Res 33:1199-1207

NRC (National Research Council) (2011) Nutrient requirements of fish and shrimp. The National Academies Press, Washington DC

Pérez J, Wicki G, Moyano J, Alarcón F (2003) Evaluación del efecto de inhibidores de proteasa presentes en ingredientes vegetales utilizables en piensos para dos especies piscícolas cultivadas en Argentina; Pacú (Piaractus mesopotamicus) y Pejerrey (Odontesthes bonaeriensis). II Congreso Iberoamericano Virtual de Acuicultura (CIVA) 442-454

Quirós J, Valverde S, Ulloa J (2014) The proteolytic digestive activity and growth during ontogeny of Parachromis dovii larvae (Pisces: Cichlidae) using two feeding protocols. Fish
Physiol Biochem 40:1253-1261. doi:10.1007/s10695-0149920-0

Rodiles A, Santigosa E, Herrera M, Hachero-Cruzado I, Cordero M, Martínez-Llorens S, Lall S, Alarcón F (2012) Effect of dietary protein level and source on digestive proteolytic enzyme activity in juvenile Senegaleses sole, Solea senegalensis Kaup 1850. Aquacult Int 20:1053-1070

Santigosa E, Sánchez J, Médale F, Kaushik S, Pérez-Sánchez J, Gallardo M (2008) Modifications of digestive enzymes in trout (Oncorhynchus mykiss) and sea bream (Sparus aurata) in response to dietary fish meal replacement by plant protein sources. Aquaculture 282:68-74

Szkudlarek M, Zakęś Z (2007) Effect of stocking density on survival and growth performance of pikeperch, Sander lucioperca (L.), larvae under controlled conditions. Aquacult Int 15:67-81

Tengjaroenkul B, Smith B, Smith S, Chatreewongsin U (2002) Ontogenic development of the intestinal enzymes of cultured Nile tilapia, Oreochromis niloticus L. Aquaculture 211(1):241-251

Toledo-Solís F, Uscanga-Martínez A, Guerrero-Zárate R et al (2015) Change on digestive enzymes during initial ontogeny in the three-spot cichlid Cichlasoma trimaculatum. Fish Physiol Biochem 41:267-279

Treviño L, Álvarez-González C, Perales-García N et al (2011) A histological study of the organogenesis of the digestive system in bay snook Petenia splendida Günther (1862), from hatching to the juvenile stage. J Appl Ichthyol 27:73-82

Uscanga-Martínez A, Moyano-López F, Álvarez-González C, Perales-García N (2011) Aplicaciones a la mejora de la utilización nutritiva del alimento en cíclidos cultivados en México. En: Cruz-Suárez L, Ricque-Marie D, Tapia-Salazar M, Nieto-López M, Villarreal-Cavazos D, GamboaDelgado J, Hernández-Hernández L (eds) Avances en Nutrición Acuícola XI - Memorias del Décimo Primer Simposio Internacional de Nutrición Acuícola. Monterrey, México, pp. 46-104

Valverde-Chavarría S, Álvarez-González C, Ulloa-Rojas J et al (2013) Ontogenia del sistema digestivo del guapote lagunero Parachromis dovii durante el periodo larval y selección de ingredientes para su alimentación. En: Cruz Suárez L, Ricque-Marie D, Tapia-Salazar M, Nieto-López M, Villarreal-Cavazos D, Gamboa-Delgado J, Álvarez-González C (eds) Avances en Nutrición Acuícola XII. XII Simposio Internacional de Nutrición Acuícola. Tabasco, México, pp 318-353

Walter H (1984) Proteinases: methods with hemoglobin, casein and azocoll as substrates. In: Bergmeyern HU (ed) Methods of enzymatic analysis, vol V. Verlag Chemic Weinheim, Berlin, pp 270-277

Zambonino-Infante J, Cahu C (2001) Ontogeny of the gastrointestinal tract of marine fish larvae. Comp Biochem Physiol C: Toxicol Pharmacol 130:477-487 